\title{
Hubungan pengawasan orang tua dalam penggunaan gadget dengan kemampuan empati anak
}

\author{
Ajeng Putri Pradevi \\ Pendidikan Guru Pendidikan Anak Usia Dini, FIP, Universitas Negeri Yogyakarta \\ Jalan Colombo No 1 Yogyakarta, Indonesia \\ E-mail: ajeng.putri2015@student.uny.ac.id
}

\begin{tabular}{|c|c|}
\hline ARTICLE INFO & ABSTRACT \\
\hline \multirow[t]{2}{*}{$\begin{array}{l}\text { Article } \\
\text { history: } \\
\text { Received:28-04-2020 } \\
\text { Revised: 06-05-2020 } \\
\text { Accepted: } 12-05-2020\end{array}$} & $\begin{array}{l}\text { Penelitian ini bertujuan untuk mengetahui hubungan antara pengawasan orang } \\
\text { tua dalam penggunaan gadget dengan kemampuan berempati anak. Hasil } \\
\text { penelitian menunjukkan bahwa, terdapat hubungan yang positif antara } \\
\text { pengawasan orang tua dalam penggunaan gadget dengan kemampuan berempati } \\
\text { anak sebesar } 0,491>0,05 \text {. Dari } 105 \text { orang tua, terdapat } 53 \text { orang tua }(50,50 \%) \\
\text { berada pada kategori pengawasan yang sangat tinggi, } 45 \text { orang tua }(42,90 \%) \\
\text { berada pada kategori tinggi, sebanyak } 6 \text { orang tua }(5,70 \%) \text { pada kategori cukup, } \\
\text { dan } 1 \text { orang tua ( } 1,00 \%) \text { berada pada kategori pengawasan yang rendah. } \\
\text { Sedangkan kemampuan berempati anak mayoritas berada pada kategori tinggi } \\
\text { yakni sebanyak } 66 \text { anak ( } 62,90 \%) \text {, pada kategori sangat tinggi sebanyak } 29 \text { anak } \\
(27,60 \%) \text {, kategori cukup sebanyak } 10 \text { anak ( } 9,50 \%) \text {, dan tidak terdapat anak } \\
\text { yang memiliki tingkat kemampuan berempati yang rendah. }\end{array}$ \\
\hline & $\begin{array}{l}\text { This study discusses about relation between parent control in using gadgets with } \\
\text { children empathy ability. The results showed that there was a positive } \\
\text { relationship between parental control in using gadgets with children empathy } \\
\text { ability on } 0.491>0.05 \text {. From } 105 \text { parents, there were } 53 \text { parents (50.50\%) } \\
\text { according to very high category, } 45 \text { parents (42.90\%) in high category, } 6 \text { parents } \\
\text { (5.70\%) in the sufficient category, and } 1 \text { parent }(1.00 \%) \text { are in low category. The } \\
\text { children empathy ability majority children are in the high category of } 66 \text { children } \\
\text { (62.90\%), in the very high category there are } 29 \text { children (27.60\%), enough } \\
\text { categories as many as } 10 \text { children (9.50\%), and not including children who have } \\
\text { low level of empathy ability. }\end{array}$ \\
\hline
\end{tabular}

\section{PENDAHULUAN}

Dewasa ini berbagai perangkat gadget seperti televisi, smartphone, tablet, laptop PC, maupun play station telah lekat dengan keseharian anak. Kabali Hilda (2013) menyatakan anakanak cenderung menggunakan perangkat gadget tersebut untuk bermain game, menonton video, dan bermain aplikasi. Penggunaan gadget yang dilakukan oleh anak tentunya tak terlepas dari peran orang tua karena pada faktanya tidak sedikit orang tua yang telah memperkenalkan gadget kepada anak sejak dini.

Kebenaran fenomena ini dirilis oleh Asian Parent pada November 2014 di Singapura, Malaysia, Thailand, Indonesia, dan Filipina yang mendapati sebanyak 98\% orang tua di Asean mengizinkan anak mereka untuk menggunakan gadget dengan harapan, pengenalan teknologi (gadget) sejak dini dapat menghindarkan anak menjadi seseorang yang gagap teknologi dan sadar akan perubahan dunia luar. Namun, disisi lain orang tua merasa khawatir ketika anak lebih mementingkan gadget dibandingkan kegiatan-kegiatan humanis seperti, bersosialisasi, makan, tidur, dan lain sebagainya.

Dilansir dari laman Mother and Baby, terdapat beberapa keuntungan penggunaan gadget yang dilakukan oleh anak diantaranya, terbiasanya anak untuk memilih informasi yang dibutuhkan dalam waktu yang singkat. Selain itu games pada gadget yang dimainkan oleh anak pada dasarnya memiliki tempo cepat sehingga anak dapat terlatih untuk cepat dalam mengambil 
Jurnal Pendidikan Anak, Volume 9 (1), Tahun 2020

Ajeng Putri Pradevi

keputusan. Games pada gadget juga dapat mengembangkan penglihatan tepi (peripheral vision) yang berefek pada kemampuan berpikir kreatif dan penyusunan strategi. Disisi lain, tak semua konten atau informasi yang diakses melalui gadget layak untuk anak. Terdapat berbagai games ataupun animasi (kartun) yang mengandung unsur kekerasan dan pornografi dapat terakses bebas.

Terlalu sering menggunakan gadget dapat menimbulkan kecanduan yang disebut dengan screen dependency disorder (SDD) atau gangguan ketergantungan terhadap layar gadget. Gangguan ini dapat dialami oleh semua kalangan usia, namun dampak yang lebih besar akan dirasakan apabila gangguan ini dialami oleh anak dibawah usia enam tahun dikarenakan, perkembangan otak anak pada masa ini terjadi begitu pesat (golden age) dan perkembangan yang terjadi pada masa ini akan memengaruhi perkembangan anak pada masa selanjutnya.

Screen dependency disorder (SDD) dapat merusak otak yakni, menyebabkan otak anak mengalami penyusutan atau kehilangan jaringan di lobus frontal, dan striatum dimana bagian tersebutlah yang membantu seseorang untuk mengatur perencanaan dan melakukan pengorganisasian. Selain itu, dampak lain yang lebih menghawatirkan adalah rusaknya jaringan insula yang berakibat pada perkembangan rasa empati dan kasih sayang anak (smartparenting.com). Mendukung pernyataan ini, Psikolog Anna Surti Ariani menyatakan bahwa kecanduan anak terhadap gadget dapat menggerus empati anak dengan lingkungannya (gaya.tempo.co).

Sebagai makhluk sosial, manusia tidak dapat mempertahankan hidupnya seorang diri. Manusia tetap membutuhkan interaksi dengan orang lain di lingkungan sekitarnya untuk memenuhi kebutuhan. Salah satu bentuk kemampuan seseorang agar berhasil berinteraksi dengan orang lain adalah empati (Farida Agus Setiawati, 2007). Taufik (2012) mencatat empati memiliki manfaat dalam arti yang luas bagi kehidupan manusia secara umum, baik dalam masyarakat, pekerjaan, maupun dalam memahami persoalan-persoalan dalam keluarga. Adanya rasa empati juga merupakan faktor penting untuk mewujudkan social capital (modal sosial) untuk menghindari konflik-konflik di masyarakat terlebih pada masyarakat multikultural seperti Indonesia.

Empati berkenaan dengan "sensitivitas" yang dapat dimaknai sebagai suatu kepekaan rasa terhadap hal yang berkaitan secara emosional. Sikap empatik merupakan bagian dari sensitivitas individu anak karena anak memiliki kepekaan rasa dan kedekatan hati pada hal-hal yang berkaitan secara emosional (Farida Agus Setiawati, 2007). Tangisan yang dimunculkan oleh bayi ketika mendengar tangisan bayi lain merupakan tanda bahwa manusia telah memiliki kemampuan untuk berempati sejak dini. Kemampuan berempati tersebut akan berkembang sesuai dengan kematangan usia, pengalaman dan stimulasi yang diperoleh anak. Berkurang atau hilangnya rasa empati dalam diri anak dapat membuat anak sulit beradaptasi dan diterima di lingkungannya. Oleh karena itu, akan merugikan apabila kesempatan anak untuk berinteraksi dengan lingkungan menjadi berkurang akibat penggunaan gadget berlebih tanpa pengawasan orang tua.

Dalam hal ini orang tua berperan untuk mengawasi penggunaan gadget yang dilakukan anak untuk menghindari dan meminimalisir dampak buruk yang dapat ditimbulkan akibat penggunaan gadget, khususnya pada kemampuan empati anak.

\section{METODE}

Penelitian ini menggunakan teknik analisis regresi untuk mengolah data penelitian yang telah diperoleh. Regresi merupakan suatu analisis yang bertujuan untuk mengetahui hubungan suatu variabel terhadap variabel lainnya, yakni adakah hubungan antara pengawasan penggunaan gadget yang dilakukan oleh orang tua dengan kemampuan berempati anak. 
Jurnal Pendidikan Anak, Volume 9 (1), Tahun 2020

Ajeng Putri Pradevi

Jenis penelitian yang digunakan dalam penelitian ini adalah penelitian kuantitatif korelasional. Muhammad Ngalim Purwanto (2010: 177) mengungkapkan bahwa, metode kuantitatif korelasional adalah penelitian yang melibatkan hubungan satu atau lebih variabel lain yang terjadi pada suatu kelompok. Terdapat dua variabel dalam penelitian ini, yaitu pengawasan orang tua dalam penggunaan gadget dan variabel kemampuan berempati. Adapun penelitian ini dilakukan di empat (4) lembaga taman kanak-kanak (TK) yang berada di wilayah Gugus II Kecamatan Tempel diantaranya, TK Ngestirini, TK Ngudirini, TK Pertiwi Margorejo, dan TK Al-Mu'in Kemiri. Penelitian dilakukan sejak dikeluarkannya surat izin penelitian oleh Badan Kesatuan Bangsa dan Politik Daerah Istimewa Yogyakarta pada tanggal 5 Maret 2019 yang membutuhkan waktu penelitian kurang lebih selama dua (2) bulan untuk melakukan observasi awal, pelaksanaan uji validitas, pengumpulan dan pengolahan data, serta untuk melakukan proses pembimbingan dan penyajian data.

Subjek penelitian ini merupakan 150 anak kelompok B di TK se-Gugus II Kecamatan Tempel. Jumlah sampel dalam penelitian ini ditentukan menggunakan pedoman yang dikembangkan oleh Isaac dan Michael dengan mempertimbangkan taraf kesalahan sebesar 5\% sehingga diperoleh jumlah sampel sebesar 105 anak. Pemilihan sampel yang diikutsertakan dalam penelitian ini dipilih menggunakan teknik purposive sampling, dimana orang tua anak yang dilibatkan dalam penelitian ini diharuskan memiliki setidaknya satu perangkat gadget dan memberikan izin pada anak untuk menggunakan gadget tersebut.

Data yang diperlukan dalam penelitian ini diperoleh dari data primer yang diperoleh melalui sebaran kuesioner yang sebelumnya telah divalidasi melalui uji expert judgement. Setelah divalidasi oleh ahli, selanjutnya instrumen kuesioner tersebut diujikan pada 50 orang tua diluar populasi penelitian. Kemudian, data validitas yang telah diperoleh, diolah menggunakan bantuan Computer Program SPSS Seri 25.0 untuk menentukan butir instrument yang valid dan tidak valid. Butir yang dinyatakan tidak valid, tidak diikutsertakan dalam instrumen penelitian ini. Setelah melalui uji validitas, kuesioner yang ada kemudian diberikan kepada sampel populasi sebagai alat untuk mengumpulkan data.

Penelitian ini melibatkan 105 orang tua anak kelompok B di empat TK yang berada di wilayah Gugus II Kecamatan Tempel yang turut memberikan informasi/data melalui kuesioner yang berisikan 18 pernyataan untuk mengukur tingkat pengawasan orang tua dalam penggunaan gadget dan 24 pernyataan digunakan untuk mengukur tingkat kemampuan berempati anak dimana setiap butir yang ada dalam kuesioner tersebut memiliki skala likert berupa empat alternatif pilihan yaitu tidak pernah, jarang, sering dan selalu. Adapun teknik analisis data dalam penelitian ini menggunakan rumus korelasi product moment Karl Pearson untuk menguji hubungan antara pengawasan orang tua dalam penggunaan gadget dengan kemampuan empati anak.

\section{HASIL DAN PEMBAHASAN}

\section{Hasil}

Hasil penelitian menunjukkan adanya hubungan yang positif antara pengawasan orang tua dalam penggunaan gadget dengan kemampuan berempati anak, namun hubungan yang dipaparkan dalam penelitian ini masih secara umum. Oleh karena itu, peneliti selanjutnya disarankan untuk dapat melakukan penelitian yang lebih mendalam terkait dengan faktor-faktor lain atau pun karakteristik responden maupun subjek yang dapat memengaruhi hubungan pengawasan penggunaan gadget dengan kemampuan empati anak. 
Jurnal Pendidikan Anak, Volume 9 (1), Tahun 2020

Ajeng Putri Pradevi

Adapun secara rinci hasil penelitian adalah sebagai berikut.

Pengawasan orang tua dalam penggunaan gadget

Tabel 1. Karakteristik orang tua berdasarkan usia

\begin{tabular}{cccc}
\hline No & $\begin{array}{c}\text { Usia } \\
\text { Orang Tua }\end{array}$ & Jumlah & (\%) \\
\hline 1 & $\leq 30$ tahun & 14 & $13,3 \%$ \\
2 & $>30$ tahun & 91 & $86,7 \%$ \\
\hline
\end{tabular}

Diketahui bahwa mayoritas responden/orang tua anak kelompok B di TK se-Gugus II Kecamatan Tempel berusia $>30$ tahun yaitu sebanyak 91 orang $(86,7 \%)$ sedangkan minoritas orang tua/responden berada pada usia $\leq 30$ tahun sebanyak 14 orang $(13,3 \%)$.

\begin{tabular}{|c|c|c|c|}
\hline No & $\begin{array}{c}\text { Pekerjaan } \\
\text { Orang Tua }\end{array}$ & Jumlah & $(\%)$ \\
\hline 1 & IRT & 36 & $34,29 \%$ \\
\hline 2 & Karyawan Swasta & 27 & $25,71 \%$ \\
\hline 3 & Wiraswasta & 12 & $11,43 \%$ \\
\hline 4 & Buruh & 17 & $16,20 \%$ \\
\hline 5 & Petani & 7 & $6,67 \%$ \\
\hline 6 & Pedagang & 1 & $0,95 \%$ \\
\hline 7 & PNS & 2 & $1,90 \%$ \\
\hline 8 & Guru & 2 & $1,90 \%$ \\
\hline 9 & TNI & 1 & $0,95 \%$ \\
\hline
\end{tabular}

Tabel 2 menunjukkan bahwa sebagian besar orang tua/responden merupakan ibu rumah tangga, yakni sebanyak 36 orang (34,29\%), kemudian orang tua yang berprofesi sebagai karyawan swasta sebanyak 27 orang (25,71\%), buruh sebanyak 17 orang (16,20\%), petani sebanyak 7 orang $(6,67 \%)$, pedagang sebanyak 1 orang $(0,95 \%)$, pegawai negeri sipil dan guru masing-masing 2 orang (1,90\%), dan TNI sejumlah 1 orang (0,95\%).

Tabel 3. Karakteristik orang tua berdasarkan pendidikan terakhir

\begin{tabular}{clcc}
\hline No & $\begin{array}{c}\text { Pendidikan } \\
\text { Orang Tua }\end{array}$ & Jumlah & (\%) \\
\hline 1 & SD & 8 & $7,62 \%$ \\
2 & SMP & 12 & $11,43 \%$ \\
3 & SMA & 75 & $71,43 \%$ \\
4 & Diploma & 6 & $5,71 \%$ \\
5 & S1 & 3 & $2,86 \%$ \\
6 & S2 & 1 & $0,95 \%$ \\
\hline
\end{tabular}

Berdasarkan Tabel 3, sebanyak 75 (71,43\%) orang tua/responden memiliki riwayat pendidikan terakhir pada bangku sekolah menengah atas (SMA-sederajat), sebanyak 12 (11,43\%) orang tua/responden merupakan tamatan sekolah menengah pertama (SMPsederajat), 8 orang tua merupakan lulusan sekolah dasar (SD-sederajat), dan 9,62\% sisanya merupakan lulusan sekolah tinggi dengan rincian, diploma sebanyak 6 orang (5,71\%), Strata-1 (S1) sebanyak 3 orang (2,86\%), dan S2 sebanyak 1 orang $(0,95 \%)$. 
Jurnal Pendidikan Anak, Volume 9 (1), Tahun 2020

Ajeng Putri Pradevi

Tabel 4. Kategori tingkat pengawasan orang tua dalam penggunaan gadget

\begin{tabular}{ccc}
\hline Kategori & Jumlah & $\mathbf{( \% )}$ \\
\hline Sangat Tinggi & 29 & $27,60 \%$ \\
Tinggi & 66 & $62,90 \%$ \\
Cukup & 10 & $9,50 \%$ \\
Rendah & 0 & $0,00 \%$ \\
\hline
\end{tabular}

Melalui data yang disajikan dalam Tabel 4 dapat diketahui bahwa sebanyak 53 orang tua (50,50\%) berada pada kategori pengawasan yang tinggi, 45 orang tua $(42,90 \%)$ berada pada kategori tinggi, sebanyak 6 orang tua (5,70\%) pada kategori cukup, sedangkan 1 orang tua $(1,00 \%)$ berada pada kategori pengawasan yang rendah.

Kemampuan empati

Tabel 5. Karakteristik anak berdasarkan jenis kelamin

\begin{tabular}{cccc}
\hline No & Jenis Kelamin & Jumlah & (\%) \\
\hline 1 & Laki-Laki & 58 & $55,20 \%$ \\
2 & Perempuan & 47 & $44,80 \%$ \\
\hline
\end{tabular}

Berdasarkan jenis kelamin, karakteristik anak kelompok B di TK se-Gugus II Kecamatan Tempel didominasi oleh anak laki-laki yang berjumlah 58 anak, sedangkan untuk anak perempuan berjumlah 47 anak.

Tabel 6. Karakteristik anak berdasarkan usia

\begin{tabular}{clcc}
\hline No & Usia Anak & Jumlah & $(\%)$ \\
\hline 1 & 5-6 tahun & 61 & $58.1 \%$ \\
2 & 6,1-7 tahun & 44 & $41.9 \%$ \\
\hline
\end{tabular}

Apabila dikategorikan berdasarkan usia, terdapat 61 anak berada pada usia 5-6 tahun (58,1\%), sedangkan 44 anak (41,9\%) berusia 6,1-7 tahun.

Tabel 7. Kategori tingkat kemampuan empati anak.

\begin{tabular}{ccc}
\hline Kategori & Jumlah & $\mathbf{( \% )}$ \\
\hline Sangat Tinggi & 53 & $50,50 \%$ \\
Tinggi & 45 & $43,90 \%$ \\
Cukup & 6 & $5,70 \%$ \\
Rendah & 1 & $1,00 \%$ \\
\hline
\end{tabular}

Kecenderungan skor variabel kemampuan berempati berada pada kategori sangat tinggi sebanyak 66 anak (62,90\%), kategori tinggi sebanyak 29 anak (27,60\%), kategori cukup sebanyak 10 anak $(9,50 \%)$, dan tidak terdapat kecenderungan skor $(0,00 \%)$ pada kategori rendah.

Setelah dilakukan pengujian menggunakan Computer Program SPSS 25.00 didapati nilai $r_{\text {hitung }}$ sebesar 0,491 lebih besar dari $r_{\text {tabel }}$ yakni 0,1599 dengan nilai signifikansi sebesar 0,000 . Dengan begitu, dapat dinyatakan bahwa terdapat hubungan positif antara pengawasan orang tua dalam penggunaan gadget dengan kemampuan berempati pada anak kelompok B di TK se-Gugus II Kecamatan Tempel, atau $H_{a}$ diterima. 
Jurnal Pendidikan Anak, Volume 9 (1), Tahun 2020

Ajeng Putri Pradevi

\section{Pembahasan}

Berdasarkan hasil penelitian diketahui bahwa tingkat pengawasan orang tua dalam penggunaan gadget anak kelompok B di TK se-Gugus II Kecamatan Tempel berada pada kategori sangat tinggi. Dari 105 orang tua, terdapat 53 orang tua (50,50\%) berada pada kategori pengawasan penggunaan gadget yang sangat tinggi, 45 orang tua $(42,90 \%)$ berada pada kategori tinggi, sebanyak 6 orang tua (5,70\%) pada kategori cukup, dan 1 orang tua (1,00\%) berada pada kategori pengawasan yang rendah.

Skor tertinggi pada variabel pengawasaan orang tua dalam penggunaan gadget terletak pada pembiasaan izin sebelum menggunakan gadget, sedangkan skor terendah diperoleh pada sub indikator penggunaan parental control. Berdasarkan hasil tersebut dapat diartikan bahwa begitu tingginya kesadaran orang tua dalam mengawasi penggunaan gadget terutama dalam melakukan pembiasaan anak dalam meminta izin sebelum menggunakan perangkat gadget. Meski demikian, masih terdapat orang tua yang belum atau kurang memaksimalkan penggunaan fitur parental control untuk mengawasi konten yang diakses oleh anak yang menyebabkan pengawasan menjadi tidak maksimal.

Tingkat kemampuan berempati anak kelompok B di TK se-Gugus II Kecamatan Tempel mayoritas berada pada kategori tinggi yakni sebanyak 66 anak (62,90\%), pada kategori sangat tinggi sebanyak 29 anak (27,60\%), kategori cukup sebanyak 10 anak (9,50\%), dan tidak terdapat anak yang memiliki tingkat kemampuan berempati yang rendah. Hal ini sesuai dengan teori tahap perkembangan empati yang dikemukakan oleh Borba Michele (2008) bahwa anak berusia 5-7 tahun telah berada pada tahap perkembangan empati kognitif dimana dua komponen empati yaitu afektif dan kognitif telah berkembang. Anak mulai mampu menalar akibat dari tindakan emosinya dan memprediksi tindakan emosi orang lain serta mampu menunjukan perilaku empati melalui bahasa verbal maupun ekspresi wajah, serta mulai mampu melakukan bantuan-bantuan yang efektif untuk membantu kesulitan orang lain melalui perilaku-perilaku berbagi mainan/makanan, mengucapkan terima kasih dan mudah memaafkan orang lain. Anak pun mulai belajar untuk mampu membantu orang lain tanpa pernah merasakan kondisi orang tersebut seperti memberikan sedekah ataupun bantuan kepada tunawisma.

Hasil pengolahan data yang telah dilakukan menunjukkan bahwa terdapat hubungan yang positif signifikan antara pengawasan orang tua dalam penggunaan gadget dengan kemampuan berempati pada anak kelompok B di TK se-Gugus II Kecamatan Tempel. Hal itu ditunjukkan melalui hasil uji hipotesis menggunakan teknik bivariate Pearson dengan product moment dari Karl Pearson. Dari pengujian itu didapati nilai $r_{\text {hitung }}$ sebesar 0,491, lebih besar dari $r_{\text {tabel }}$ yaitu $0,1599(0,491>0,1599)$ dengan nilai signifikansi sebesar 0,000 lebih kecil dari $0,05(0,000<0,05)$. Hasil pengolahan data yang diperoleh mendukung rumusan hipotesis alternatif yang telah dikemukakan pada bab II dimana terdapat hubungan yang positif antara pengawasan orang tua dalam penggunaan gadget dengan kemampuan berempati anak kelompok B di TK se-Gugus II Kecamatan Tempel. Artinya, semakin tinggi pengawasan orang tua dalam penggunaan gadget, maka semakin tinggi pula kemampuan berempati anak. Hasil penelitian ini sesuai dengan pendapat Farida Agus Setiawati (2007) bahwa salah satu cara untuk mengembangkan kemampuan berempati dapat dilakukan dengan pembiasaan yang salah satunya melalui pembiasaan aturan penggunaan gadget yang dilakukan orang tua sebagai salah satu upaya mengawasi penggunaan gadget anak. Hasil penelitian ini juga sesuai dengan pendapat Muhammad Hafiz Al-Ayouby (2017) bahwa penggunaan gadget yang dilakukan anak dapat berdampak positif maupun negatif sesuai dengan pengawasan dan arahan orang tua sebagai contoh yang baik bagi anak.

Data selanjutnya diperoleh bahwa nilai determinasi korelasi ( $R$ Square) sebesar 0,241 yang artinya variabel pengawasan orang tua dalam penggunaan gadget memiliki hubungan yang positif dengan variabel kemampuan berempati sebesar $24,1 \%$, sedangkan $75,9 \%$ 
dipengaruhi oleh variabel lain yang tidak diteliti dalam penelitian ini. Hal ini selaras dengan teori yang dikemukakan oleh Saphiro Lawrence (1997) bahwa terdapat beberapa faktor yang memengaruhi kemampuan berempati seseorang, yakni faktor kognitif dimana semakin matangnya perkembangan otak maka pemahaman orang akan sikap empati semakin bertambah. Kedua, faktor bawaan, dimana gender dapat memengaruhi kecenderungan tindakan empatik. Kemudian faktor pendidikan, keluarga, dan pengalaman perilaku empatik. Faktor-faktor tersebut akan bernilai positif apabila diterapkan dengan baik.

\section{SIMPULAN}

Tingkat pengawasan orang tua dalam penggunaan gadget pada anak kelompok B di TK se-Gugus II Kecamatan Tempel terbilang sangat tinggi, sedangkan tingkat kemampuan berempati anak kelompok B di TK se-Gugus II Kecamatan Tempel mayoritas berada pada kategori tinggi.

Telah dibuktikan bahwa terdapat hubungan yang positif signifikan antara pengawasan orang tua dalam penggunaan gadget dengan kemampuan berempati anak di TK se-Gugus II Kecamatan Tempel. Artinya semakin tinggi pengawasan gadget yang dilakukan orang tua, semaki tinggi pula tingkat kemampuan berempati anak.

Orang tua perlu mempertahankan pengawasan gadget yang telah diterapkan agar penggunaan gadget yang dilakukan anak dapat memberikan pengaruh yang positif terhadap tumbuh kembangnya. Orang tua dapat memanfaatkan gadget untuk meningkatkan kemampuan berempati anak melalui konten-konten edukatif mengenai sikap tenggang rasa, penuh pengertian, dan peduli sesama baik dengan menggunakan video yang berkaitan dengan fenomena sosial ataupun memalui berbagai games yang mengandung nilai berempati seperti games merawat hewan peliharaan, dan lain sebagainya.

Sangat tingginya pengawasan orang tua terhadap penggunaan gadget memiliki andil terhadap tingginya kemampuan berempati anak. Untuk itu, para guru disarankan untuk memberikan motivasi ataupun dukungan kepada orang tua untuk senantiasa memberikan pengawasan terhadap penggunaan gadget yang dilakukan oleh anak. Dukungan yang diberikan dapat berupa arahan personal maupun melalui kegiatan parenting mengenai pengawasan gadget, serta memberikan kegiatan-kegiatan kooperatif/prososial di sekolah yang dapat meningkatkan kemampuan berempati anak untuk mengimbangi penggunaan gadget di rumah.

Hasil penelitian menunjukkan adanya hubungan yang positif antara pengawasan orang tua dalam penggunaan gadget dengan kemampuan berempati anak, namun hubungan yang dipaparkan dalam penelitian ini masih secara umum. Oleh karena itu, peneliti selanjutnya disarankan untuk dapat melakukan penelitian yang lebih mendalam terkait dengan faktor-faktor lain atau pun karakteristik responden maupun subjek yang dapat memengaruhi hubungan pengawasan penggunaan gadget dengan kemampuan berempati anak.

\section{UCAPAN TERIMA KASIH}

Peneliti mengucapkan terima kasih kepada berbagai pihak yaitu para dosen di jurusan PAUD, para subjek penelitian, dan pihak lainnya yang telah memberikan dukungan dan dorongan sampai terselesaikannya penelitian ini. 
Jurnal Pendidikan Anak, Volume 9 (1), Tahun 2020

Ajeng Putri Pradevi

\section{DAFTAR PUSTAKA}

Al-Ayouby, H. (2017). Dampak penggunaan gadget pada anak usia dini (Studi di PAUD dan TK.Handayani Bandar Lampung). Diakses pada tanggal 9 Januari 2018 pukul 19.30 WIB melalui http://digilib.unila.ac.id.

Borba, M. (2008). Membangun kecerdasan moral. Jakarta: Gramedia Pustaka Utama.

Elicay, K. (8 Januari 2018). Screen dependency disorder is real, and it damages your child's brain. https://www.smartparenting.com.

Fajrina, H.N. (4 November 2015). Tingkat kecanduan gadget di usia dini semakin menghawatirkan. https://www.cnnindonesia.com.

Kabali, H., Irigoyen, M.M, Davis, R.N., et al. (2015). Exposure and use of mobile media devices by young children. Diambil pada tanggal 30 Maret 2019, dari https://pediatrics.aappublications.org.

Prihendityo, E. (28 November 2016). Anak pecandu gawai resahkan orang tua. https://www.cnnindonesia.com.

Purwanto, N. (2010). Evaluasi hasil belajar. Yogyakarta: Pustaka Pelajar.

Redaksi. (29 September 2014). Anak kecanduan gadget, ada dampak fisik dan psikis. https://gaya.tempo.co.

Redaksi. (27 januari 2017). 4 dampak positif gadget. https://www.motherandbaby.co.id.

Setiawati, F.A. (2007). Social life skill untuk anak usia dini: empati. Yogyakarta: Tiara Wacana.

Shapiro, Lawrence. (1997). Mengajarkan Kecerdasan Emosional Pada Anak. Jakarta: Gramedia Utama. 